\title{
BAHASA DAN AGAMA MENURUT FALSAFAH ANALITIK BRITISH: RESPONS LINGUISTIK MELAYU
}

\section{(Language and Religion According to British Analytical Philosophy:Malay Linguistic Response)}

\author{
Munif Zarirruddin Fikri Nordin \\ munif@uum.edu.my
}

Pusat Pengajian Bahasa, Tamadun dan Falsafah, Universiti Utara Malaysia.

Sila rujuk: Munif Zariruddin Fikri Nordin. (2022). Bahasa dan Agama menurut Falsafah Analitik British: Respons Linguistik Melayu. Melayu: Jurnal Antarabangsa Dunia Melayu, 15(1), 49-68. http://doi.org. 10.37052/jm.15(1)no3

\begin{tabular}{|lllll}
$\begin{array}{l}\text { Peroleh: } \\
\text { Received: 13/8/2021 }\end{array}$ & $\begin{array}{l}\text { Semakan: } \\
\text { Revised }\end{array}$ & 10/12/2021 & $\begin{array}{l}\text { Terima: } \\
\text { Accepted: 14/12/2021 }\end{array}$ & $\begin{array}{l}\text { Terbit dalam talian: } \\
\text { Published online: }\end{array}$
\end{tabular}

\begin{abstract}
Abstrak
Dalam falsafah agama, bahasa berfungsi sebagai medium pengungkapan makna keagamaan, seperti bersifat deskriptif dan kebolehtentuan benar-salah dalam mistisisme. Dalam falsafah bahasa pula, agama merupakan salah satu latar atau konteks dalam penghasilan makna dan interpretasi yang bersifat keagamaan. Hal ini memperlihatkan simbiotisme bahasa dan agama dalam falsafah agama dan falsafah bahasa. Artikel ini membincangkan kedudukan bahasa dan agama dalam kedua-dua falsafah berkenaan dari sudut pandang dua ahli falsafah abad ke-20 aliran falsafah analitik British, iaitu Hick dan Ayer, dengan objektif (1) mengenal pasti titik pertemuan bahasa dan agama dalam falsafah, (2) memperincikan garis sempadan bahasa dan agama mengikut pembahagian falsafah bahasa dan falsafah agama, dan (3) mengupas respons linguistik Melayu terhadap produk pemikiran falsafah analitik British. Fokus analisis ialah metafizik. Penghujahan metafizik dianalisis berdasarkan fungsi bahasa dalam falsafah agama yang Hick (1990) ketengahkan dalam Philosophy of Religion, dan juga latar agama dalam falsafah bahasa yang Ayer (1936) kemukakan menerusi Language, Truth and Logic.
\end{abstract}

(C) Dewan Bahasa dan Pustaka. 2022. This work is licensed under the term of the Creative Commons Attribution (CC BY) (http://creative commons.org/licenses/by/4.0/)

ISSN 1675-6460 e-ISSN 2682-8049 
Kata kunci: Analisis wacana agama, bahasa dan agama, fungsi bahasa, falsafah linguistik, falsafah agama, respons linguistik Melayu

\begin{abstract}
In philosophy of religion, language serves as a medium of expression of religious meaning, as it is descriptive and possesses true-false faculty in mysticism. In philosophy of language, religion is one of the backgrounds or contexts in the production of religious meaning and interpretation. This shows the symbiotism of language and religion within the philosophy of religion and philosophy of language. This article discusses the position of language and religion within the two philosophies from the viewpoints of two 20th century British analytic philosophers, namely Hick and Ayer, with the objectives of: (1) identifying the meeting point of language and religion in philosophy; (2) detailing the boundaries of language and religion according to the division of linguistic philosophy and religious philosophy, and; (3) parsing the Malay linguistic response to the products of British analytic philosophical thought. The focus of analysis is metaphysics. The metaphysical arguments were analysed based on the function of language in the philosophy of religion that Hick (1990) highlighted in Philosophy of Religion, as well as the religious background in the philosophy of language that Ayer (1936) put forward in Language, Truth and Logic.
\end{abstract}

Keywords: Religious discourse analysis, language and religion, language function, linguictics philosophy, religious philosophy, Malay linguistic responses

\title{
PENGENALAN
}

Falsafah agama ialah kajian permasalahan umum falsafah mengenai agama dan Tuhan, seperti persoalan teologi tabii tentang apakah yang dianggap agama, atau persoalan hujah ontologi tentang bolehkah pernyataan agama diinterpretasi secara literal (Lacey,1986: 208-9). Falsafah bahasa pula ialah kajian permasalahan umum berkenaan bahasa, dan tidak tertumpu pada sesuatu bahasa tertentu seperti dalam linguistik, umpamanya persoalan ciri sejagat yang dimiliki oleh setiap bahasa, atau persoalan bahasa buatan yang digunakan dalam pengkomputeran (Lacey,1986: 120), atau persoalan cara pengungkapan bahasa dalam ritual agama.

Berdasarkan pengertian tersebut, wujudkah pertautan antara falsafah agama dan falsafah bahasa? Jika wujud, apakah yang mempertautkan kedua-duanya? Benarkah terdapat satu titik pertemuan yang sukar dibezakan yang mempertautkan 
falsafah bahasa dan falsafah agama? Benarkah satu garis sempadan yang kabur memisahkan kedua-duanya?

Terdapat banyak contoh bagi menjelaskan persoalan tersebut. Misalnya, bagaimanakah memahami makna perintah pemotongan tangan dalam al-Quran (ayat 5:38) yang dikategorikan sebagai hudud? Adakah semua jenis dan bentuk kecurian disabitkan dengan hukuman pemotongan tangan? Adakah pemotongan yang Allah maksudkan sama seperti pemotongan yang manusia fahami, iaitu pengeratan atau pemenggalan? Adakah maksud tangan yang dipotong meliputi keseluruhan tangan atau sebahagian kecil? Apakah ritual dalam proses pemotongan tersebut?

Begitu juga dengan persoalan tentang interpretasi ayat mutasyabihat dalam al-Quran, khususnya yang mengandungi pemerihalan tentang sifat-sifat Allah. Apakah makna sebenar yang sepatutnya difahami? Adakah wajar ayat mutasyabihat dimaknakan dengan makna literal yang difahami daripada sifat manusia? Atau adakah wajar ayat tersebut dibiarkan tanpa apa-apa makna?

Artikel ini membincangkan kedudukan bahasa dan agama dalam falsafah dari sudut pandang dua ahli falsafah abad ke-20 aliran falsafah analitik British, iaitu John Hick dan A.J. Ayer, dengan objektif (1) mengenal pasti titik pertemuan bahasa dan agama dalam falsafah, (2) memperincikan garis sempadan bahasa dan agama mengikut pembahagian falsafah bahasa dan falsafah agama, dan (3) mengupas respons linguistik Melayu terhadap produk pemikiran falsafah analitik British.

Fokus perbincangan ialah bahasa agama yang mengandungi makna berkaitan metafizik dan bersifat transenden. Hujah metafizik Hick (1990) dianalisis berdasarkan karya penting beliau Philosophy of Religion (Fourth Edition), manakala hujah metafizik Ayer (1936) pula bersumberkan karya utama beliau Language, Truth and Logic.

Pemilihan kedua-dua ahli falsafah aliran falsafah analitik British adalah atas justifikasi bahawa mereka merupakan pendukung utama yang mempertalikan bahasa dan agama dalam falsafah pada abad ke-20 dan pengaruh mereka masih dominan sehingga sekarang. Pemilihan mereka juga bukan bermaksud menerapkan pemikiran falsafah Barat dalam usaha memahami makna dan interpretasi teks Islam; sebaliknya meneladani pengalaman dan penyelesaian mereka untuk menangani persoalan metafizik.

\section{ALIRAN FALSAFAH ANALITIK BRITISH, HICK DAN AYER}

Falsafah analitik British ialah tradisi falsafah yang dominan sehingga kini, khususnya di negara yang penduduknya bertutur dalam bahasa Inggeris. Perkataan analitik yang 
dinisbahkan kepada aliran falsafah ini merujuk metode analisis logik dan linguistik yang mendasarinya (Papineau, 1989:11).

Falsafah analitik British mengadunkan rasionalisme (Decartes) dan empirisisme (Locke, Berkeley and Hume) melalui sintesis Kant pada penghujung abad ke-18. Selepas Kant, tokoh utama aliran ini pada penghujung abad ke-19 ialah Frege, dan kemudiannya pada abad ke-20 ialah Russell and Wittgenstein. Adunan rasionalisme dan empirisisme melahirkan positivisme logik dengan tumpuan untuk memajukan kajian logik dan falsafah bahasa. Ahli falsafah bahasa lain yang turut mengembangkan aliran falsafah ini termasuklah Austin, Strawson dan Dummett (Papineau, 1989:12).

Hick ialah ahli falsafah agama yang berpengaruh. Selain daripada Philosophy of Religion, beliau juga menghasilkan Evil and the God of Love dan An Interpretation of Religion. Antara hasil sumbangan Hick yang penting ialah pengesahan eskatologi yang berfungsi sebagai alat pengukuran ungkapan agama. Menurut beliau, kejahatan boleh diukur melalui hubungannya dengan perkembangan spiritual atau pembentukan jiwa. Selain itu, beliau mengusulkan idea Kant tentang pluralisme agama (Quinn, 1995:354).

Hick menjadi terkenal dengan kontroversi pluralisme agama dan kritikan pedas terhadap doktrin Kristian ortodoks. Beliau juga mengeluarkan pandangan bahawa doktrin kebangkitan semula selepas kematian sebaik-baiknya dianggap sebagai sebuah mitos (Quinn, 1995:354).

Ayer pula merupakan ahli falsafah bahasa yang bersemangat ateis dan sering mengkritik ajaran Kristian yang beliau anggap tidak rasional (Ayer, 1936:xi). Antara tahun 1929-1932, Oxford menyediakan latar penting falsafah bahasa Ayer melalui aliran neo-Hegelian and Aristotlelian untuk mengembangkan pemikiran analisis logik (logical analysis) beliau (Ayer, 1936:xi). Karya Ryle, Moore dan Russell dalam kalangan pengasas falsafah analitik British melalui jalur pemikiran Cambridge merupakan antara rujukan pembacaan beliau. Beliau juga menekuni pemikiran empirisisme Hume selain pemikiran positivisme logik Wittgenstein.

Positivisme logik atau empirisisme logik mendukung kuat nilai empirisisme dengan menolak metafizik dan menjunjung tinggi nilai sains. Dalam hubungan dengan bahasa, aliran ini juga menegaskan bahawa sesuatu yang boleh diujarkan sepatutnya boleh diungkapkan dari segi proposisi asasnya. Semua penyataan aras tinggi, daripada pemerihalan bentuk yang paling mudah ditembusi kepada hipotesis saintifik yang paling abstrak, sepatutnya boleh diterjemahkan tanpa kehilangan maknanya (Ayer, 1936:xii). 
BAHASA DAN AGAMA MENURUT FALSAFAH ANALITIK BRITISH: RESPONS LINGUISTIK MELAYU

\section{HUJAH HICK TENTANG BAHASA DALAM FALSAFAH AGAMA}

Hick (1990: 82) menyifatkan bahasa agama sebagai bahasa aneh (the peculiarity of religious language). Keanehan ini menarik minat falsafah moden untuk menganalisis penggunaan keagamaan bahasa. Meskipun bahasa agama ialah isu yang pernah mendapat tempat dalam sejarah falsafah, namun falsafah analitik, khususnya aliran British meniupkan semangat baharu dan penyegaran semula dengan fokus kepada fungsi asas bahasa agama.

Dengan membangkitkan persoalan metafizik, seperti mencintai Tuhan dalam keadaan Dia tidak dapat dilihat serta persoalan memahami sifat-sifat Tuhan melalui antropomorfisme, Hick (1990: 83) berhujah bahawa tidak mungkin Tuhan bersifat dengan sifat yang sama dengan manusia, kerana Tuhan tidak berjasad, bertempat atau bernafsu.

Hick (1990: 83-99) juga memberikan respons kepada lima doktrin dan teori bahasa agama yang dikemukakan oleh ahli falsafah agama seperti yang berikut:

1. Doktrin analogi Aquinas: Hick (1990: 83) mendapati doktrin untuk menerangkan sifat Tuhan melalui sifat manusia ini tidak berupaya mengungkapkan karakter kesempurnaan Tuhan kerana ada sifat Tuhan yang sama sekali tidak dapat dianalogikan dengan manusia.

2. Doktrin sifat simbolik bahasa agama Tillich: Hick (1990:85) menolak doktrin yang membandingkan tanda dan simbol untuk menunjukkan terdapat sesuatu yang lain di sebalik kedua-duanya ini. Hick berhujah bahawa tanda mengandungi makna arbitrari, manakala simbol pula sebaliknya, iaitu tidak arbitrari kerana simbol mengandungi hubungan dalaman dengan realiti yang dilambangkan.

3. Teori bukan kognitif Randall: Hicks (1990:90) mempertikaikan teori ini yang mengandaikan bahawa Tuhan ialah sebuah projeksi atau binaan mental yang bersifat sementara dengan posisi Tuhan tersudut di penjuru ruang masa; yang menafikan Tuhan sebagai Pencipta dan Pemilik alam semesta.

4. Teori bukan kognitif Braithwaite: Hick (1990:93) menolak teori ini yang menegaskan bahawa bahasa agama mempunyai fungsi etika yang menggambarkan kepatuhan pengungkapnya kepada sebab tindakannya dan pada masa yang sama mencadangkan orang lain melakukan tindakan yang sama. 


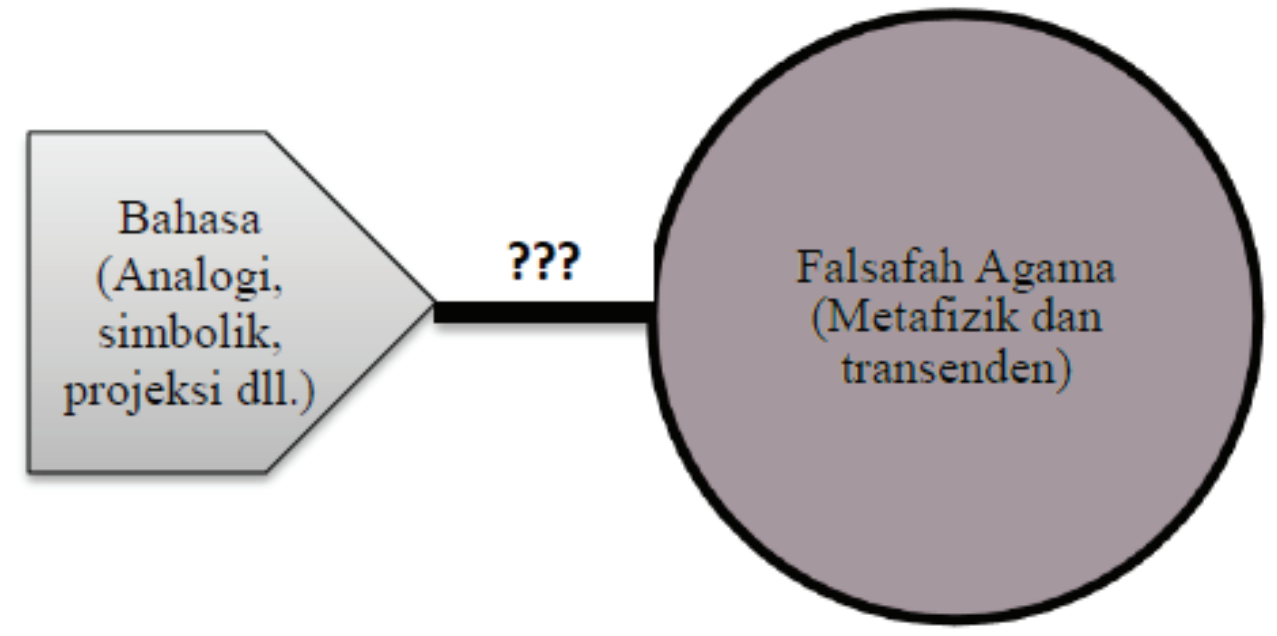

Rajah 1 Bahasa dalam falsafah agama menurut Hick.

5. Teori bukan kognitif permainan bahasa Wittgenstein dan Philips: Hick (1990:96) menyanggah teori yang menganggap bahasa umpama satu permainan; misalnya bahasa agama berbeza dengan bahasa sains meskipun kedua-duanya menyentuh perkara yang sama, seperti asal usul kejadian manusia.

Hujah dan respons Hick memperlihatkan fungsi penting bahasa dalam analisis falsafah agama. Bahasa disifatkan sebagai alat pengungkapan yang penuh unik dan istimewa. Melalui bahasa, makna keagamaan diungkapkan dan disampaikan kepada para penganut agama. Walau bagaimanapun, dalam pengungkapan tersebut, masih terdapat makna yang tidak mengandungi hakikat sebenar realiti pengungkapan. Dengan kata lain, dalam bahasa agama, masih terdapat makna-makna keagamaan yang transenden, yang tidak dapat dijelaskan oleh bahasa, sama ada melalui analogi, simbolik atau projeksi, seperti penjelasan tentang kewujudan dan sifat-sifat Tuhan. Kedudukan ini ditunjukkan dalam Rajah 1.

Hal ini juga pernah ditegaskan oleh Ramsey (1957:46) dalam falsafah agamanya bahawa bahasa agama ialah bahasa yang berpusatkan "Tuhan" sebagai kata kuncinya. Dengan demikian, bahasa agama sekalipun struktur nahunya ringkas, namun struktur logiknya ganjil kerana maknanya sukar difahami secara tersurat. 


\section{HUJAH AYER TENTANG AGAMA DALAM FALSAFAH BAHASA}

Pada tahun 1936, melalui Language, Truth and Logic, Ayer memperkenalkan idea logik moden melalui sintesis positivisme logik dalam falsafah analitik British (Ayer, 1936:xiii). Idea ini mengusulkan penggunaan prinsip keabsahan dalam penghujahan bahawa penyataan keagamaan dan metafizik tradisional adalah tidak bermakna (Baldwin, 2001:6). Akan tetapi, usahanya tidak mendapat sambutan dalam kalangan ahli falsafah tradisional di Oxford yang mempertahankan metafizik.

Menurut Ayer (1936:13), banyak ujaran metafizik terlibat dengan kesalahan logik, dan bukannya keinginan secara sedar para pengujarnya untuk melewati batas pengalaman mereka. Bukti pancaindera dikaitkan dengan kurniaan gerak hati intelektual yang membolehkan para pengujarnya mengetahui fakta yang tidak dapat diketahui melalui pengalaman pancaindera. Sekalipun mereka mendakwa bahawa mereka bergantung pada premis empirik, namun kecenderungan mereka kepada dunia bukan empirik secara logiknya tidak dapat dijustifikasikan.

Ketidakberhasilan percubaan menjangkaui batasan pengalaman pancaindera dapat disimpulkan bukan dari sudut hipotesis psikologi, tetapi dari sudut peraturan yang menentukan signifikan literal bahasa. Ahli metafizik dipertikaikan bukan kerana mereka cuba membuktikan kefahaman tentang sesuatu yang mereka tidak alami, tetapi kerana mereka menghasilkan ayat yang gagal mematuhi syarat-syarat ayat yang mempunyai makna secara literal (Ayer, 1936: 15).

Oleh itu, Ayer (1936: 16-7) mengusulkan satu formula pengujian untuk menentukan ketulenan fakta dalam proposisi ayat yang dinamakan sebagai kriteria pengesahan. Kriteria ini terdiri daripada pengesahan prinsip dan pengesahan pada praktis. Sebagai contoh, proposisi bahawa: "Terdapat gunung-ganang di sudut yang paling jauh di bulan. Tiada roket setakat ini yang dicipta yang membolehkan saya berkunjung dan menyaksikan sudut yang paling jauh di bulan tersebut. Oleh itu, saya tidak dapat memutuskan perkara itu melalui pemerhatian sebenar", ialah proposisi yang mengandungi pengesahan pada prinsip dan bukan praktis. Kriteria ini ditunjukkan dalam Rajah 2.

Berdasarkan hujah Ayer (1936), pengaruh besar Lingkaran Vienna dapat dikesan. Melalui Wittgenstein, lingkaran ini yang dinaungi oleh Moritz Schlick, Frederich Waismann dan Rudolf Carnap meninggalkan kesan yang besar terhadap falsafah bahasa Ayer. Kelompok ini mengusulkan bahawa untuk menjadikan falsafah sebagai satu pemerhatian yang saintifik, penyataan metafizik dan transenden perlu ditolak atas sifatnya yang tidak memiliki makna. 


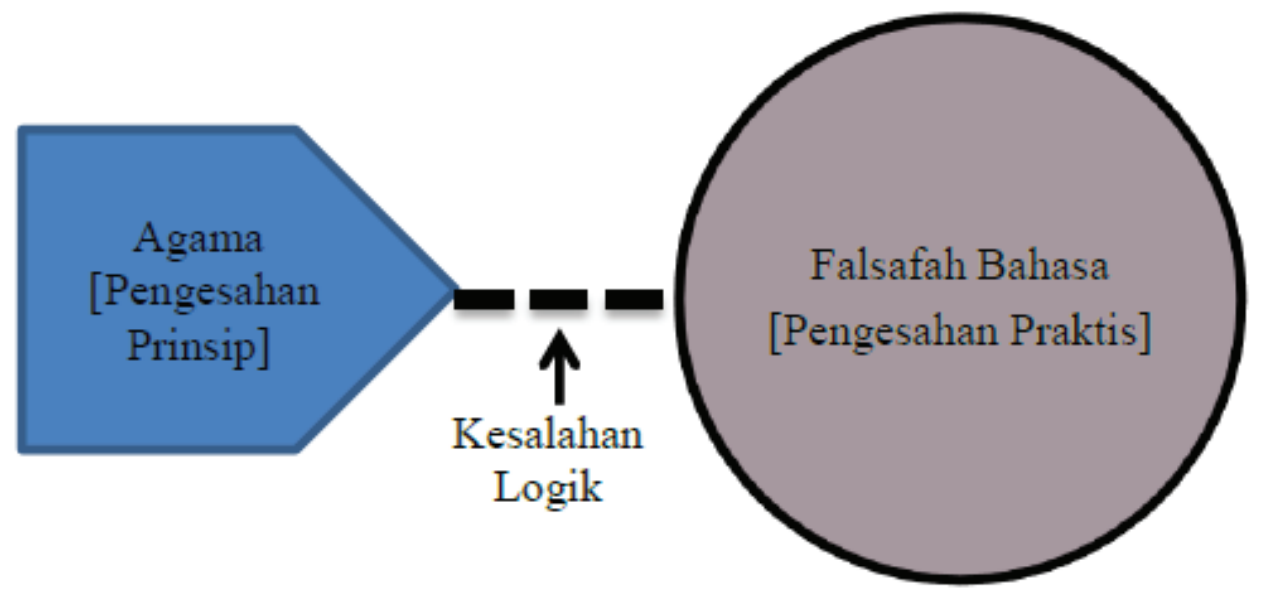

Rajah 2 Agama dalam falsafah bahasa menurut Ayer.

Tractatus Logico-Philosophicus yang Wittgenstien hasilkan pada 1922 telah menarik minat kelompok Lingkaran Vienna dan kemudiannya disintesiskan oleh Ayer bersama falsafah analitik British, khususnya mengenai ungkapan metafizik yang dianggap oleh Wittgenstein sebagai satu proposisi yang benar, tetapi bukan dalam bentuk sebenar seperti yang diungkapkan (Lazenby, 2006:4-5).

Pengaruh Wittgenstein terhadap Ayer melalui Philosophical Investigations pula dipengaruhi oleh penghujahan Wittgenstein bahawa "agama dalam bahasa" ialah bahan analisis falsafah tentang ungkapan kebahasaan yang terkandung dalam praktis dan kepercayaan sesebuah komuniti agama. Makna, proses dalaman, kriteria dan persekitaran dalam pengungkapan bahasa agama menjadi latar utama kritikan Wittgenstein terhadap bahasa persendirian, yang berbeza dengan bahasa awam (Sherry, 1977:8).

\section{TITIK PERTEMUAN BAHASA DAN AGAMA DALAM FALSAFAH}

Di sebalik perbezaan, terdapat titik pertemuan antara bahasa dan agama dalam falsafah. Nilai keunikan bahasa dan idea logik keagamaan mempertemukan falsafah agama dan falsafah bahasa dalam satu persamaan, iaitu interpretasi makna. Hujah Hick yang berkisar tentang kualiti bahasa agama sebagai bahasa persendirian, manakala hujah Ayer yang tertumpu pada tahap penerimaan logik terhadap makna keagamaan mengisyaratkan bahawa makna tidak mampu difahami dengan mudah. Titik pertemuan bahasa dan agama dalam kedua-dua penghujahan tersebut ialah 


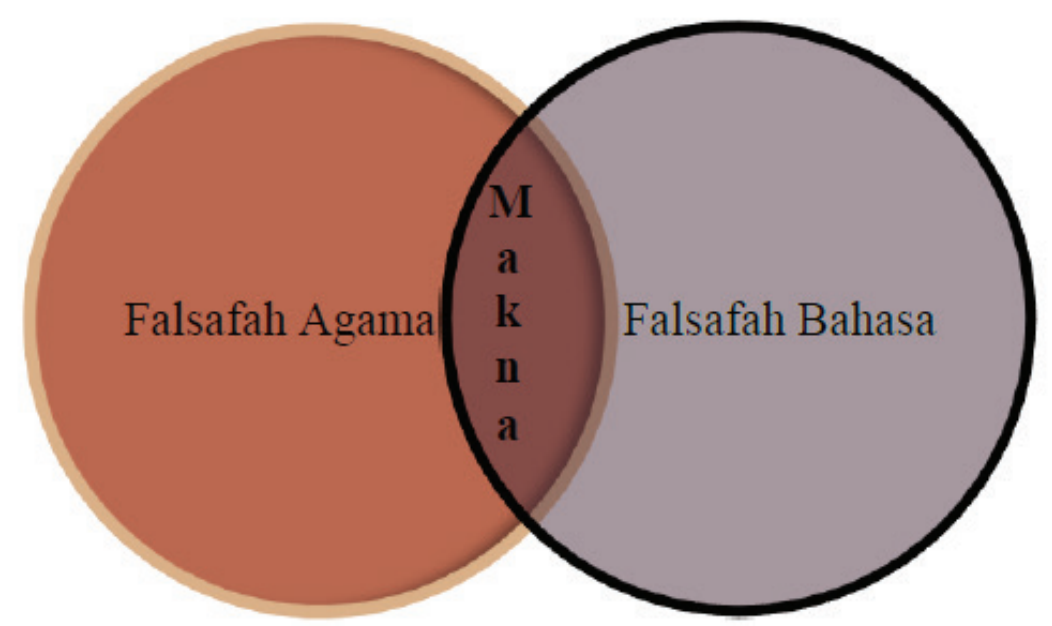

Rajah 3 Titik pertemuan bahasa dan agama menurut Hick dan Ayer.

terdapatnya banyak makna keagamaan yang masih belum difahami dengan jelas. Ketidakjelasan makna ini membuka ruang kepada penyemakan dan penghasilan semula makna, termasuk makna baharu.

Dalam Rajah 3, titik pertemuan bahasa dan agama dalam falsafah ialah makna. Isu tentang makna berfungsi merancakkan dan merangsang perbahasan melalui soalan yang dikemukakan dan jawaban yang diberikan. Dalam hal ini, terdapat beberapa kedudukan makna, seperti:

1. Makna yang tidak jelas atau kabur yang perlu kepada penjelasan.

2. Makna yang telah diberikan penjelasan, tetapi tidak relevan dengan keperluan semasa.

3. Makna yang telah diberikan penjelasan, tetapi relevan di sesetengah tempat dan tidak relevan di sesetengah tempat lain.

4. Makna yang telah diberikan penjelasan, tetapi tidak tepat berdasarkan penemuan terkini.

5. Makna yang telah diberikan penjelasan, tetapi tidak dipersetujui.

6. Makna yang memerlukan kesepakatan penerimaan. 


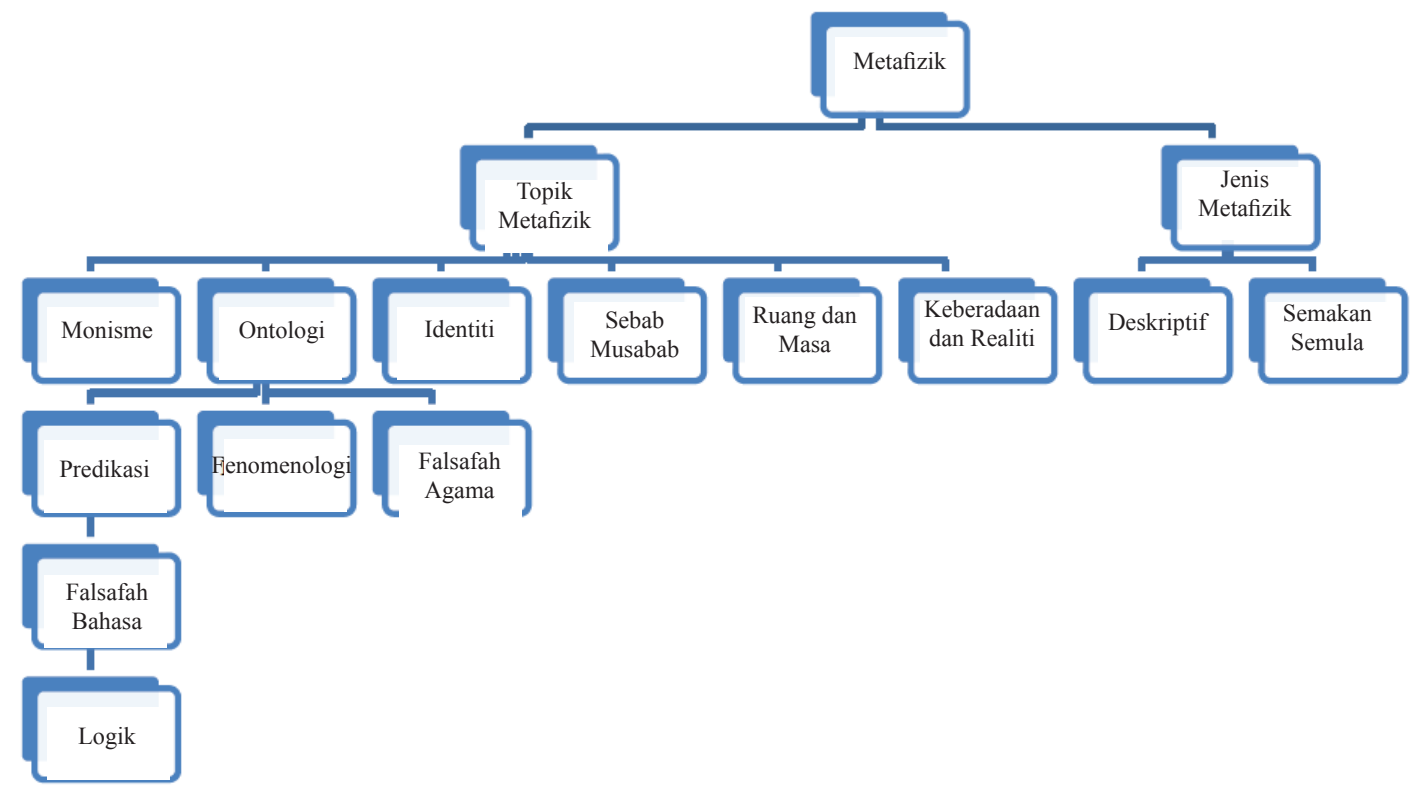

Rajah 4 Hubungan Metafizik dengan Falsafah Bahasa (Sumber: Honderich, 1995:934)

Terdapat hubungan metafizik yang signifikan dalam perbahasan falsafah bahasa dan falsafah agama. Dalam Rajah 4, Honderich (1995) mengutarakan hubungan tersebut. Antara topik metafizik yang disenaraikan ialah monisme, ontologi, identiti, sebab musabab, ruang dan masa, serta keberadaan dan realiti. Dalam ontologi sebagai contoh, perbahasan falsafah bahasa melibatkan logik, sementara perbahasan falsafah agama pula membabitkan Tuhan.

Hal ini bermaksud bahawa bahasa berfungsi mengetengahkan logik keagamaan yang boleh diterima oleh akal. Dalam konteks kepercayaan sebahagian Muslim di Malaysia, sebelum akal mengambil tempat, terdapat peranan wahyu yang wajib diimani dan diterima terlebih dahulu. Misalnya, isu pelaksanaan hukum hudud yang pernah menjadi perdebatan hangat satu masa dahulu. Melalui pertimbangan akal, hudud secara literal dijustifikasikan sebagai penyelesai masalah jenayah. Melalui pertimbangan iman (wahyu) pula, hudud dijustifikasikan sebagai perintah Ilahi yang mengandungi kebaikan yang wajib dilaksanakan dan tidak perlu dipersoalkan lagi. Titik pertemuan bahasa dan agama dalam perdebatan ini ialah bentuk pelaksanaan 
hudud yang sebenarnya, seperti yang dikehendaki oleh Allah SWT. Dengan kata lain, bentuk pelaksanaan hudud ialah isu makna yang memerlukan penjelasan, kesesuaian dan kesepakatan dalam kalangan masyarakat.

\section{GARIS SEMPADAN BAHASA DAN AGAMA DALAM FALSAFAH BAHASA DAN FALSAFAH AGAMA}

Secara perbandingan, falsafah bahasa dan falsafah agama dipisahkan oleh sempadan makna dan konteks. Pandangan Hick (1990) dan Ramsey (1957) bahawa makna agama masih sukar difahami disebabkan bahasa yang digunakan; dan pendapat Ayer (1936) dan Wittgenstein (Keightley, 1976) bahawa bahasa yang mengungkapkan makna keagamaan ialah bahasa persendirian memperlihatkan simbiotisme bahasa dan agama pada titik sempadan falsafah bahasa dan falsafah agama.

Rajah 5 memaparkan simbiotisme bahasa dan agama sebagai subjek perbahasan falsafah bahasa dan falsafah agama. Namun begitu, yang memisahkan keduadua falsafah berkenaan ialah makna dan konteks. Falsafah agama memerihalkan bahasa sebagai medium yang mengandungi makna, sementara falsafah bahasa pula memperincikan konteks agama dalam penginterpretasian makna.

Dalam Rajah 6, berdasarkan lakaran Honderich (1995), konteks agama dalam cabang falsafah bahasa yang beliau ajukan ialah ciri-ciri metafizik dalam penjelasan tentang idea semula jadi yang terkandung dalam praandaian bahasa.

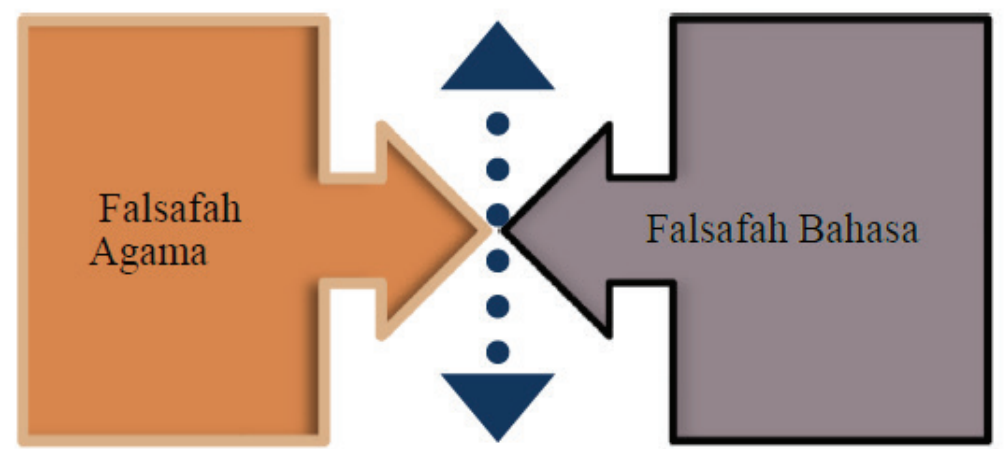

Makna | Konteks

Rajah 5 Hubungan dalam falsafah bahasa.

(Sumber: Honderich, 1995: 937) 


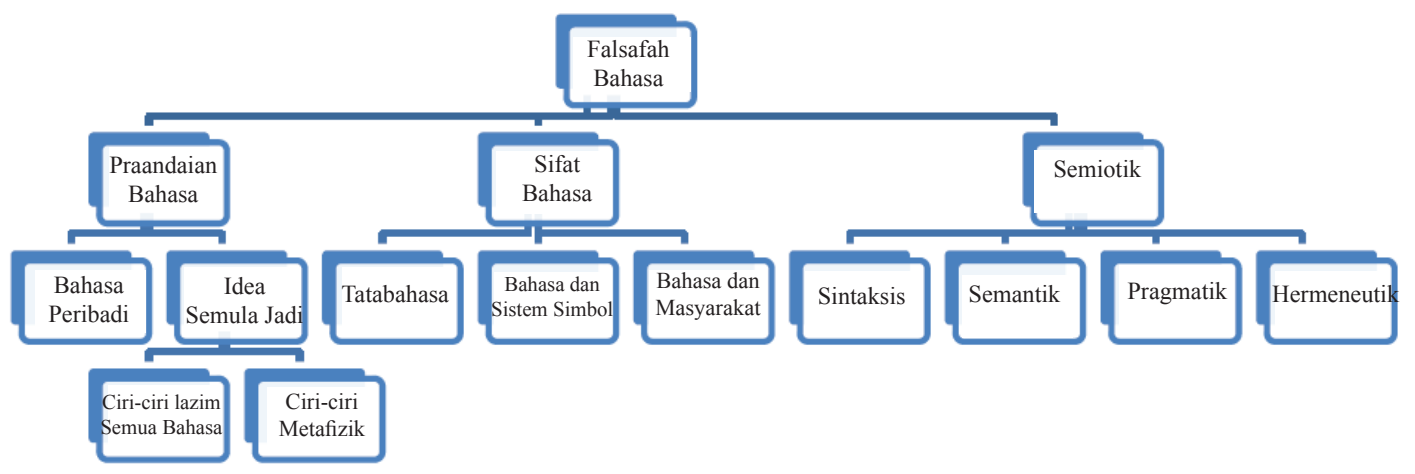

Rajah 6 Hubungan Metafizik dengan Falsafah Bahasa (Sumber: Honderich, 1995:934).

Contoh konteks agama ini boleh diperluas kepada isu pelaksanaan hukum hudud yang dibincangkan sebelum ini. Konteks yang dimaksudkan ialah latar pelaksanaan hukum berkenaan diperintahkan, seperti waktu, sama ada waktu sekarang ialah waktu yang sama dengan konteks ayat berkenaan diturunkan.

Seperti yang telah dinyatakan sebelum ini, oleh sebab terdapat perbezaan tafsiran tentang makna sebenar, maka hudud menjadi isu yang hangat diperkatakan dalam masyarakat Malaysia yang berbilang agama dan etnik, mulai awal 1990-an lagi. Hal ini demikian kerana isu hudud bukan hanya menjadi isu agama, tetapi juga menjadi isu politik (Islam lawan sekular) dan isu perundangan (Norhashimah, 1994).

Namun begitu, isu hudud sebagai isu agama ternyata lebih menonjol dan lebih utama berbanding sebagai isu politik dan perundangan. Keadaan ini disebabkan oleh perpecahan yang berlaku dalam masyarakat Islam sendiri akibat perbezaan fahaman tentang pelaksanaan hudud. Pada asasnya, orang Islam di Malaysia faham bahawa hudud ialah hukuman bagi kesalahan yang dinyatakan dalam al-Quran. Akan tetapi, mereka berbeza fahaman tentang latar dan konteks pelaksanaan hukuman tersebut.

Nasr Hamid (1994, 2005) pernah mencadangkan konsep berikut bagi menghuraikan maksud latar dan konteks agama berkenaan:

1. Kebudayaan teks (hadārat al-nașs), iaitu keterikatan teks dengan budaya.

2. Kebudayaan interpretasi (hadārat al-ta'wīl), iaitu keterikatan interpretasi dengan budaya.

3. Penghasilan makna (intāj al-dalāat), iaitu kefahaman dan pemaknaan ditentukan oleh daya intelektual dan horizon budaya. 
BAHASA DAN AGAMA MENURUT FALSAFAH ANALITIK BRITISH: RESPONS LINGUISTIK MELAYU

4. Sisi lain bagi teks (al-wajh al-äkhar li al-nașș), iaitu kewujudan unsur intelektual manusia yang dimasukkan dalam pentafsiran.

5. Teks ilahi (nașṣ ilāhì), iaitu keberadaan teks dalam keadaan asal kewahyuan.

6. Teks manusiawi (nașs insānn̄), iaitu keberadaan teks menurut kefahaman manusia.

7. Kefahaman mutlak (fahm mutlaq) tidak wujud dalam pentafsiran bersifat individu.

8. Kefahaman relatif (fahm nisbiy) paling ideal dalam pentafsiran.

9. Kepelbagaian pentafsiran (al-ta'addud al-ta 'wiliy) wujud sepanjang tradisi Islam.

10. Al-Quran ialah produk budaya (muntaj thaqāfiy) kerana bahasanya ialah bahasa yang difahami hasil keterikatannya dengan linguistik, budaya dan realiti tempatan.

Walau bagaimanapun, Nasr Hamid sendiri berdepan dengan kecaman dan dilabel sebagai liberalis, khususnya daripada golongan majoriti arus perdana yang berhujah bahawa konsep yang beliau cadangkan dipengaruhi oleh pemikiran falsafah bahasa fahaman Barat yang materialistik, khususnya hermeneutik (Nur Zainatul, Latifah \& Muhd Najib, 2015; Azmil, 2017). Apa-apa jua pemikiran yang materialistik mesti ditolak dan tidak boleh digunakan untuk mentafsirkan makna atau menjelaskan maksud teks agama Islam, khususnya al-Quran dan hadis. Mereka juga berhujah bahawa metodologi pentafsiran sedia ada, seperti ilmu tafsir dan ulum al-Quran sudah memadai dan tidak perlu dipertikaikan lagi kerana memiliki nilai keabsahan dan kebolehpercayaan yang tinggi.

\section{RESPONS LINGUISTIK MELAYU TERHADAP PRODUK PEMIKIRAN FALSAFAH ANALITIK BRITISH}

Pada umumnya, kajian tentang bahasa dan agama dari perspektif falsafah seumpama falsafah analitik British, yang ditulis dalam bahasa Melayu sangat kecil bilangannya. Pengkaji yang besar pengaruhnya ialah Syed Muhammad Naquib al-Attas (1978; 2001; 2007; 2020) melalui Islam and Secularism, Risalah untuk Kaum Muslimin, Tinjauan Ringkas Peri Ilmu dan Pandangan Alam, dan Islam: The Concept of 
Religion and the Foundation of Ethics and Morality, yang sekurang-kurangnya boleh dianggap sebagai empat penulisan penting bahasa dan agama dari perspektif falsafah Islam. Keempat-empat penulisan tersebut memuatkan gagasan pemikiran beliau tentang islamisasi ilmu, yang merupakan respons terhadap pemikiran Barat yang beliau anggap sekular dan bercanggah dengan Islam, termasuk tentang metafizik.

Dari sudut linguistik, setakat ini tiada respons secara langsung dalam kalangan ahli linguistik Melayu tentang bahasa dan agama menurut falsafah analitik British. Persoalan di sini ialah mengapakah linguistik Melayu lesu? Terdapat beberapa kemungkinan tentang kelesuan tersebut, iaitu sama ada mereka tidak mengetahui, tidak menyedari, tidak mengambil peduli atau tidak memberikan perhatian tentang hal tersebut. Bagi setiap kemungkinan, terdapat alasan, iaitu sama ada hal tersebut tiada kepentingan kepada linguistik Melayu untuk diketahui dan disedari mahupun tiada kaitan dengan linguistik Melayu untuk diambil peduli dan diberikan perhatian.

Misalnya, tulisan al-Attas (2020) dalam Islam: The Concept of Religion and the Foundation of Ethics and Morality, yang asalnya ialah teks syarahan beliau pada Persidangan Islam Antarabangsa, di London, pada 5 April 1976, merupakan satu seruan supaya perhatian tidak diberikan kepada pemikiran Barat berhubung dengan persoalan falsafah umumnya serta persoalan bahasa dan agama khususnya. Dalam tulisan ini, al-Attas (2020:47) menegaskan bahawa semangat ingin tahu dalam budaya dan tamadun Barat berasal daripada kekecewaan terhadap agama. Semangat ingin tahu berkenaan pada dasarnya digerakkan oleh keraguan dan ketegangan dalaman. Ketegangan dalaman merupakan hasil daripada pertembungan unsur-unsur yang bercanggah dan nilai-nilai yang bertentangan dalam dualisme yang berterusan, manakala keraguan pula mengekalkan keadaan ketegangan dalaman tersebut. Ketegangan dalaman seterusnya menghasilkan keinginan yang tidak pernah puas ke arah pencarian dan memulakan perjalanan penemuan yang berterusan. Pencarian dan perjalanan tersebut terus subur kerana keraguan sentiasa berlaku sehingga mengakibatkan yang dicari tidak pernah benar-benar ditemui, dan yang ditemui tidak pernah benar-benar memenuhi matlamat hakiki.

Seruan al-Attas (2020) ini meninggalkan mesej bahawa kegiatan "berfalsafah" seperti produk pemikiran falsafah analitik British dalam artikel ini tidak digalakkan kerana hasilnya hanya membawa kepada kemunculan lebih banyak keraguan dan kecelaruan. Sisi negatif falsafah analitik British dikaitkan dengan pengalaman kehidupan sekular Barat yang berpaksikan manusia sebagai entiti fizikal di samping meletakkan keupayaan intelektual sepenuhnya sebagai penyelesai misteri kehidupan. Sisi negatif juga dihubungkan dengan penolakan falsafah analitik British terhadap 
BAHASA DAN AGAMA MENURUT FALSAFAH ANALITIK BRITISH: RESPONS LINGUISTIK MELAYU

ilmu dan kepercayaan berteraskan kepastian agama yang bersumberkan ilmu wahyu seperti yang difahami dan dilalui dalam Islam.

Pada premis yang sama, al-Attas (2020: 46) berhujah bahawa "berfalsafah" yang Islami, yang dinyatakan dalam al-Quran, iaitu melalui tiga peringkat atau tahap kepastian ilmu:

1. Kepastian yang diperoleh melalui kesimpulan, sama ada deduktif atau induktif ('ilm al-yaqin).

2. Kepastian yang diperoleh oleh penglihatan langsung ('ain al-yaqin).

3. Kepastian yang diperoleh melalui pengalaman langsung (haqq al-yaqin).

Menurut al-Attas (2020:46), tiga tahap kepastian ini mempunyai kaitan dengan kebenaran, sama ada yang nyata atau tersembunyi, empirikal atau transenden. Dengan kata lain, kepastian ilmu tentang perkara yang tersembunyi mempunyai kekuatan kepastian yang sama seperti perkara yang nyata. Tahap kepastian ini mempunyai kaitan dengan yang dirasakan oleh organ kognisi rohani, perasaan, dan kepastian tersebut dalam ilmu dirujuk sebagai kepercayaan dan iman.

Di luar lingkungan pemikiran Melayu, seruan al-Attas seumpama ini tidak terlepas daripada kritikan semula, termasuk oleh kalangan pengkaji falsafah Islam yang tidak bersetuju dengan hujah kritikan beliau. Antara yang dimaksudkan ialah Majid Fakhry (1997:157), yang menyifatkan al-Attas seorang fundamentalis, yang dicirikan oleh pegangan kepada keunggulan Islam sebagai satu-satunya agama yang benar-benar global dan merangkumi setiap aspek kehidupan manusia, peribadi atau awam, rohani atau duniawi, serta bertentangan pula dengan agama Kristian yang menekankan aspek rohani sahaja. Menurut Majid (1997:157) lagi, al-Attas sering membuat kenyataan yang tidak wajar atau mencadangkan teori yang tidak mungkin dapat dipadankan, misalnya kenyataan bahawa agama tidak pernah berakar dalam tamadun Barat kerana tamadun berkenaan menyesatkan dunia dan menganjurkan kehidupan sekular. Selain itu, matlamat al-Attas dalam kebanyakan tulisan falsafah beliau adalah untuk mencetuskan polemik, dan bukannya untuk memberikan maklumat atau menyedarkan pembacanya, sama ada Muslim atau Kristian (Majid, 1997: 157).

Respons linguistik Melayu yang dapat dikesan ialah pelanjutan hujah alAttas bahawa bahasa Melayu perlu dibebaskan daripada pengaruh sekularisme dan dimasukkan roh Islam. Pelanjutan ini dapat difahami dan ditelusuri, misalnya melalui tulisan Hashim Hj. Musa (1994), Wan Mohd Nor Wan Daud (2010; 2013) 
dan Awang Sariyan $(2017 ; 2020)$ yang mewakili pengaruh pemikiran al-Attas dan aliran falsafah islamisasi ilmu beliau di Malaysia.

Hashim (1994) mengangkat beberapa pemikiran al-Attas tentang transendental bahasa, konsep lapangan semantik dan bahaya aliran falsafah rasionalisme dan sekularisme Barat untuk memahami falsafah bahasa. Misalnya, transendal bahasa sangat nyata dimiliki oleh bahasa Arab sebagai bahasa al-Quran, melalui keterangan sifatnya sebagai penerang tanda yang paling jelas dan pengungkap makna yang paling teratur (Hashim, 1994: 42). Bahaya aliran falsafah rasionalisme dan sekularisme Barat diingatkan pula kerana pertentangannya dengan Islam dari segi epistemologi ilmu. Dalam Islam, ilmu mestilah diyakini datang daripada Tuhan dan diperoleh oleh manusia melalui saluran pancaindera yang benar, laporan yang benar berdasarkan autoriti, akal fikiran yang benar, dan intuisi (ilham) (Hashim, 1994:105).

Awang dan Abdul Rasid (2021) kemudiannya memperincikan lagi peranan bahasa yang digolongkan dalam kategori ilmu tanzil sebagai naratif abadi dalam kehidupan manusia yang berpaksikan agama berdasarkan epistemologi Islam. Dengan demikian, bahasa dan metafizik Islam contohnya hanya boleh diperincikan dan ditentukan kebenarannya berdasarkan epistemologi Islam sahaja.

Sekiranya kelesuan tentang hal ini dibiarkan berlanjutan bersandarkan alasan bahawa respons terhadap falsafah analitik Barat khususnya hanya akan membawa kepada kemunculan lebih banyak keraguan dan kecelaruan, lama-kelamaan falsafah bahasa Melayu akan ketinggalan jauh berbanding dengan falsafah bahasa lain, termasuk falsafah bahasa Indonesia. Di Indonesia, penghujahan metafizik sebagai manifestasi produk pemikiran falsafah analitik British seperti yang diutarakan oleh Hick dan Ayer mahupun pendekatan hermeneutik dalam analisis wacana agama seperti yang dikemukakan oleh Nasr Hamid bukanlah asing dan baharu, yang perlu dijauhi apalagi dimusuhi. Memang benar terdapat pro dan kontra tentang baik dan buruk falsafah analitik British. Walau bagaimanapun, setiap pro dan kontra dalam falsafah merupakan proses yang mematangkan, menambah baik dan mengukuhkan kegiatan falsafah itu sendiri. Tanpa pro dan kontra, falsafah tidak akan berkembang kerana tiada lagi soal jawab; dan pada masa yang sama, pro dan kontra tersebut juga perlu dikawal oleh etika dan peraturan supaya tidak mengakibatkan permusuhan dan persengketaan.

Pengintelektualan bahasa Melayu tentang metafizik misalnya, antara lain sepatutnya dicirikan oleh pengungkapan falsafah pada tahap tertinggi serta sepatutnya diisi oleh penggunaan bahasa Melayu untuk tujuan "berfalsafah". Yang dimaksudkan dengan "berfalsafah" bukanlah sekadar memiliki sekian banyak pendapat dan pandangan tentang metafizik, tetapi juga memikirkan secara mendalam tentang metafizik dengan bahasa Melayu sebagai alat pemikiran tersebut. 
Persoalan seterusnya ialah bagaimanakah linguistik Melayu memberikan respons kepada kelesuan ini? Ada dua cadangan tindakan. Pertama, kursus falsafah bahasa perlu ditawarkan dalam program pengajian linguistik bermula pada peringkat ijazah pertama di institusi pengajian tinggi. Kandungan kursus falsafah bahasa perlu disegarkan dan diperluas skopnya; bukan hanya tentang sejarah falsafah bahasa, tetapi juga tentang cakupan falsafah bahasa sejajar dengan trend semasa pada abad ke-21, seperti pemikiran dalam aliran falsafah analitik British, falsafah Perancis, falsafah Jerman dan sebagainya. Pertindihan antara kursus falsafah bahasa dengan kursus falsafah teras universiti, iaitu Falsafah dan Isu Semasa perlu dielakkan. Selain itu, pembelajaran dan pengajaran kursus falsafah bahasa perlu dipelbagaikan kaedahnya; bukan hanya tentang penghafalan biografi tokoh atau peristiwa, tetapi juga tentang penerapan nilai preskriptif dan spekulatif falsafah bahasa dalam kehidupan seharian, yakni tentang kegunaannya dalam penyelesaian masalah dan membuat keputusan, termasuk peranan bahasa dalam usaha memahami persoalan metafizik.

Kedua, kajian tentang falsafah bahasa perlu dirancakkan dan disemarakkan oleh ahli-ahli linguistik Melayu. Seyogia diakui bahawa adalah sukar untuk mendapatkan geran penyelidikan untuk membiayai kajian tentang falsafah bahasa mutakhir ini. Kesukaran itu bukan hanya disebabkan oleh masalah kekurangan dana, khususnya geran kerajaan dan swasta tempatan, tetapi juga disebabkan oleh ketidakfahaman pihak pembiaya tentang peranan dan kepentingan falsafah bahasa dalam pembangunan sosial dan negara. Sehubungan dengan itu, peranan dan kepentingan falsafah bahasa perlu diketengahkan dan ditonjolkan kepada khalayak supaya salah faham tersebut dapat diperbetul. Misalnya, hubungan falsafah bahasa dengan penginterpretasian makna metafizik dalam teks agama sama ada literal atau figuratif diterangkan dengan jelas dan saintifik sehingga terzahir outputnya. Di samping itu, wacana tentang hubungan bahasa dengan agama dari sudut falsafah perlu diperbanyak termasuk diberikan tempat dan ruangan dalam media cetak dan media elektronik supaya peranannya dapat difahami dan dibuktikan.

\section{KESIMPULAN}

Terdapat banyak pemaknaan bahasa agama yang terbuka kepada penginterpretasian semula atau penyemakan interpretasi. Misalnya, dalam al-Quran, ayat mutasyabihat tentang sifat-sifat Allah ialah ayat yang mengandungi pemerihalan mistisisme atau metafizik yang memerlukan pemaknaan yang jelas dan tepat. Dalam konteks ini, penerapan pemikiran falsafah sangat diperlukan. Terdapat interpretasi retrospektif 
yang terikat dengan makna lampau dan dianggap mutlak dan terdapat juga interpretasi prospektif yang luwes dan terbuka.

Artikel ini mengenal pasti titik pertemuan antara bahasa dan agama dalam falsafah seperti yang digariskan dalam objektif pertama, iaitu ketidakjelasan makna agama yang membuka ruang kepada penyemakan dan penghasilan semula makna, termasuk makna baharu. Oleh itu, bahasa perlu berfungsi mengetengahkan logik keagamaan yang boleh diterima oleh akal. Realiti dalam pemaknaan agama atau pelaksanaan sesuatu perintah agama merupakan isu makna yang memerlukan penjelasan, kesesuaian dan kesepakatan dalam kalangan masyarakat melalui fungsi bahasa.

Selain itu, artikel ini memperincikan garis sempadan bahasa dan agama mengikut pembahagian falsafah bahasa dan falsafah agama, iaitu makna dan konteks. Falsafah agama memerihalkan bahasa sebagai medium yang mengandungi makna, manakala falsafah bahasa pula memperincikan konteks agama dalam penginterpretasian makna. Sekalipun makna dan konteks mempunyai garis sempadan, tetapi keduaduanya saling melengkapi. Makna tidak lengkap tanpa konteks agama, dan konteks tidak mempunyai erti tanpa makna agama. Oleh yang demikian, penggunaan bahasa agama perlu dipengaruhi oleh makna dan konteks agama yang betul menurut penilaian intelektual yang saintifik dan empirik. Atas nama agama, semantik "suci", "berkat", "pahala", "syurga" dan sebagainya dalam bahasa agama hadir dalam penginterpretasiannya. Namun begitu, makna bahasa agama yang hakiki belum tentu dapat dimuktamadkan. Pemaksaan supaya sesuatu makna diterima sedang makna yang lain ditolak sering kali berlaku dalam penginterpretasian bahasa agama, yang lazimnya turut diiringi dengan pelabelan agama, seperti kafir, fasik dan munafik, sehingga mengakibatkan perpecahan dan permusuhan dalam kalangan masyarakat.

Artikel ini mendapati linguistik Melayu tidak responsif secara positif terhadap produk pemikiran falsafah analitik British. Oleh itu, dicadangkan supaya linguistik Melayu memanfaatkan pengalaman dan perkembangan positif falsafah Barat dalam menghubungkan bahasa dan agama. Tidak semua produk falsafah analitik British bertentangan dengan pengukuran kebenaran makna keagamaan yang ditentukan oleh falsafah Islam yang menjadi teras aliran pemikiran dalam falsafah Melayu. Banyak aspek yang boleh disumbangkan oleh simbiotisme bahasa dan agama terhadap perkembangan falsafah bahasa Melayu sekiranya respons linguistik Melayu dapat dibangkitkan daripada kelesuannya.

Alasan bahawa respons terhadap falsafah analitik British khususnya dan falsafah Barat amnya hanya akan menimbulkan lebih banyak keraguan dan kecelaruan merupakan alasan yang naif. Alasan tersebut dikhuatiri boleh menjadi perangkap 
dalam zon selesa ciptaan sendiri yang mengekang dinamisme falsafah Melayu, pada ketika produk pemikiran falsafah bangsa lain lebih dikenali kerana sumbangannya yang signifikan kepada falsafah dan kehidupan manusia sejagat.

Pengetahuan tentang Hick dan Ayer daripada aliran falsafah analitik British melalui karya mereka merupakan perkongsian pengalaman tentang fenomena bahasa dan agama dalam falsafah Barat. Kesungguhan mereka mengupas persoalan metafizik memperlihatkan ketinggian sifat ingin tahu mereka secara intelektual mencari jawapan tentang persoalan yang mereka kemukakan. Sifat falsafah yang silang dan pelbagai disiplin menjadikan bahasa dalam falsafah agama dan agama dalam falsafah bahasa sentiasa dinamis dan inklusif. Hal ini selaras dengan salah satu pengertian falsafah, iaitu pencarian kebenaran dan pengetahuan tentang alam semesta, kewujudan manusia, persepsi, dan tingkah laku, yang dilakukan melalui refleksi, penaakulan dan penghujahan (Chambers Concise Dictionary, 2004).

\section{RUJUKAN}

Al-Attas, Syed Muhammad Naquib (1978). Islam and Secularism. Islamic Youth Movement of Malaysia.

Al-Attas, Syed Muhammad Naquib (2001). Risalah untuk kaum Muslimin. Institut Antarabangsa Pemikiran dan Tamadun Islam.

Al-Attas, Syed Muhammad Naquib (2007). Tinjauan ringkas peri ilmu dan pandangan alam. Penerbit Universiti Sains Malaysia.

Al-Attas, Syed Muhammad Naquib (2020). Islam: The concept of religion and the foundation of ethics and morality. Ta'dib International.

Ayer, A. J. (1936). Language, Truth and Logic. London: Penguin Books.

Azmil Zainal Abidin (2017). Idea penafsiran semula al-Quran menurut Nasr Hamid Abu Zayd: Suatu pengamatan kritis. Afkar, 19(1), 113-128.

Awang Sariyan (2017). Pemikiran Awang Sariyan dalam pemartabatan bahasa Melayu. Dewan Bahasa dan Pustaka.

Awang Sariyan (2020). Masa depan Bahasa Melayu di Nusantara. Ceramah Arif Budiman 16. Capaian pada 7 Jun 2021 daripada https://academyofsingaporeteachers.moe.edu. sg/docs/librariesprovider6/resources-files/ceramah-arif-budiman/jilid-4/12-cab-16--prof-datuk-dr-awang-sariyan.pdf

Awang Sariyan \& Abdul Rasid Jamian (2021). Naratif abadi dalam pengajian dan pendidikan bahasa. PENDETA: Journal of Malay Language, Education and Literature, 12(1), 1-12. https://doi.org/10.37134/pendeta.vol12.1.fa.1.2021 
MELAYU: JURNAL ANTARABANGSA DUNIA MELAYU JILID 15 BIL. 1 JANUARI 2022

Baldwin, T. (2001). Contemporary philosophy: Philosophy in English since 1945. Oxford University Press.

Chambers Concise Dictionary (2004). Chambers Harrap.

Hashim Hj. Musa (1994). Pengantar falsafah bahasa. Dewan Bahasa dan Pustaka.

Hick, J. (1990). Philosophy of Religion. Fourth Edition. Prentice Hall.

Honderich, T. (Ed) (1995). The Oxford companion to philosophy. Oxford University Press.

Keightley, A. (1976). Wittgenstein, grammar and God. Epworth Press.

Lacey, A. R. (1986). A dictionary of philosophy. Routledge.

Lazenby, J. M. (2006). The Early Wittgenstein on Religion. Continuum.

Majid Fakhry (1997). Islamic philosophy. Oneworld Publications.

Nasr Hamid Abu Zaid (1994). Naqd al-Khitāb al-Dīniy. Kaherah: Sīnā li al-Nasyr.

Nasr Hamid Abu Zaid (2005). Isykāliyyāt al-Qirā'aț wa Āliyyāt al-Ta'wīl. Beirut: Al-Markaz al-Thaqāfiy al-'Arabiy.

Norhashimah Mohammad Yasin (1994). Islamisation or Malaynisation? A study on the role of Islamic Law in the economic development of Malaysia: 1969-1993. Tesis PhD. Universiti Warwick.

Nur Zainatul Nadra Zainol, Latifah Abdul Majid \& Muhd Najib Abd Kadir (2015). Implikasi pentafsiran Nasr Hamid Abu Zayd terhadap isu wanita dalam al-Qur'an. Islamiyyat, $37(2), 153-161$.

Papineau, D. (1989). Analytic Philosophy. Dalam Urmson, J. O. \& Rée, J. (Eds.). The concise encyclopedia of Western philosophy and philosophers. Unwin Hyman Ltd.

Ramsey, I. T. (1957). Religious language. SCM Press.

Quinn, P. L. (1995). Hick, John. Dalam Honderich, T. (Ed). The Oxford companion to philosophy. Oxford: Oxford University Press.

Sherry, P. (1977). Religion, truth and language-games. The MacMillan Press Ltd.

Wan Mohd Nor Wan Daud (2010). Al-Attas: A real reformer and thinker. Dalam Wan Mohd Nor Wan Daud \& Muhammad Zainiy Uthman (Eds.) Knowledge, language, thought and the civilization of Islam. Penerbit Universiti Teknologi Malaysia.

Wan Mohd Nor Wan Daud (2013). Islamization of contemporary knowledge and the role of the university in the context of de-Westernization and decolonization. Professorial Inaugural Lecture Series. Penerbit Universiti Teknologi Malaysia. 